\title{
THE ROLE OF GAMING TECHNOLOGIES IN INCREASING MOTIVATION AND THE DEVELOPMENT OF ORAL SPEECH IN THE CLASSROOM ON RFL (RUSSIAN AS A FOREIGN LANGUAGE)
}

\section{Mashkhura Aminovna Khafizova}

Senior Teacher, Department "Uzbek Language And Literature", Samarkand State Institute Of Architecture And Civil Engineering, Independent Researcher At Samarkand State Institute Of Foreign Languages, Uzbekistan

\section{ABSTRACT}

This article reveals the basic concepts of educational technologies and considers games as one of the types of technologies. The article provides a definition of the game, the characteristics of motivation and the needs for game activity. The author presents the basic pedagogical foundations of the organization of game activity. The methodology of the article is based on the effective use of various modern pedagogical approaches, accompanied by game technologies in the study of Russian as a foreign language. The practical significance of the article lies in the possibility of further application of situational role-playing games, both in psychological and pedagogical activities and in the educational process.

KEYWORDS:- Motivation, technology, pedagogical technologies, motives, game technologies, didactic games, game functions, role-playing games, game activity.

\section{INTRODUCTION}

"We all know that Uzbekistan has rich natural resources, powerful economic and human potential. But still, our greatest wealth is the enormous intellectual and spiritual potential of our people" [1, p. 39].

Teaching the Russian language in the world as the second main language has increased the need for modernization of the content, the use of foreign experience in teaching methods in its particular issues of teaching the Russian language. Currently, teaching Russian as a foreign language is actively developing as a relevant and promising direction. Mastering the basics of the Russian language is a prerequisite for performing educational and professional activities while studying at a non-linguistic university.

An urgent problem is to increase the motivation of students to study the Russian language, in particular in a non-linguistic university, to search for methods, techniques and technologies to improve the efficiency of the educational process, as well as to support active verbal communication during classroom lessons. The solution to this problem requires the use of new pedagogical and game technologies. 
CURRENT RESEARCH JOURNAL OF PEDAGOGICS 2(10): 17-21, October

2021 DOI: https://doi.org/10.37547/pedagogics-crjp-02-10-04

ISSN 2767-3278

(C)2021 Master Journals

Crossref doi 81 Google

Accepted 08 ${ }^{\text {th }}$ October, 2021 \& Published $13^{\text {th }}$ October, 2021

\section{THE MAIN FINDINGS AND RESULTS}

Professional motivation for teaching the Russian language is a driving factor in personal development and professional education. The problem of students' interest in mastering general education disciplines is a significant pedagogical problem both in school education and in the university. As practice shows, very few students are engaged to the fullest extent of their capabilities. This idea has been known in pedagogy for a long time. Socrates was one of the first to talk about the importance of learning motivation. Learning motivation is one of the main problems of domestic and foreign pedagogy and psychology. Now motivation is being studied from the point of view of analyzing human behavior. The intellectual level and abilities of the learner are very important in obtaining an education, but motivation is one of the decisive factors for successful learning. When determining the level of interest in the study of a subject (motivation) of a student, it is important to understand what goals are driving the student, i.e. the nature of his motives. To understand the educational motivation of students, it is important to determine the motives that actually act in a particular group, and the teacher's task is to build educational activities in such a way that the organization of educational activities corresponds to the student's internal motives.

To increase the motivation of students, V.A. Sukhomlinsky proposes to use group work in the lesson, build a lesson at a pace that is comfortable for children, create tasks on the subject that go beyond the program, with which you can develop the student's creative and abstract thinking, as well as an obligatory factor to increase motivation to study the subject, V.A. Sukhomlinsky considers the creation of a situation of success in class and taking into account the emotional factor in connection with the mental activity of a person [2, p. 320]. According to psychologists, the motivation created by the game should be presented along with communicative, cognitive and aesthetic motivation. All this taken together constitutes the motivation for learning. The most powerful motivating factor is teaching methods that satisfy the students' need for the novelty of the material being studied, for the variety of exercises performed.

Recently, the concept of pedagogical technology has firmly entered the pedagogical lexicon. The word "technology" comes from the Greek word "techne" - art, craftsmanship, skill and "logos" science, law. Literally "technology" is the science of craftsmanship. The concept of "pedagogical technologies" made its way into pedagogical science for several decades. With the introduction of technology into the educational process in the West, they started talking about teaching technology, linking it at first with technical teaching aids. The universities have expanded the concept of "teaching technology" to the term "pedagogical technologies", understanding by this the meaningful technique of the educational process [3, p. 344]. Pedagogical technologies and learning theory are interrelated and interdependent. Based on this position, we will consider the use of pedagogical gaming technologies in the conditions of higher education. Game technologies are an integral part of educational technologies. The place and role of game technology in the educational process, the combination of elements of play and learning largely depend on the teacher's understanding of the functions and classification of didactic games. The lack of a holistic definition of the game leads to the fact that until now, as we managed to find out, there is no generally accepted classification of game teaching methods, and in the literature there are many different names for the same games. Let's take as 
CURRENT RESEARCH JOURNAL OF PEDAGOGICS 2(10): 17-21, October

2021 DOI: https://doi.org/10.37547/pedagogics-crjp-02-10-04

ISSN 2767-3278

(C)2021 Master Journals

Crossref do: 81 Google

Accepted 08th October, 2021 \& Published $13^{\text {th }}$ October, 2021

a basis the classification proposed by G.K. Selevkoiv [4, p. 67], in which games are classified on various grounds. First of all, the division of games occurs according to the type of activity. Here they distinguish between physical (motor), intellectual (mental), labor, social and psychological.

The game has the following characteristics: "Is a type of human activity that can recreate other types of human activity; "A kind of unproductive activity, the motive of which is not the result, but the process itself; "An independent social structure, implying a competition between two or more opposing sides, as well as limited by procedures and rules in order to achieve the victory of one of the parties; "A formally organized system of rivalry between its participants. From an educational point of view, play is a way of group dialogical exploration of the possibilities of reality in the context of personal interests [5, p. 5].

In other words, play is an interactive method that allows one to learn from one's own experience through a specially organized and regulated "living" in a life and professional situation.

E.A. Pokrovsky believes that games are the elementary life of a class. He argues that the value of play is a factor in fostering initiative, self-activity, mental and physical qualities of a future person capable of further selfimprovement, who will eventually become a worthy citizen of his Motherland [6, p. 143].

The ability to communicate is one of the main criteria for assessing the proficiency of a foreign language and is especially urgently demanded by modern realities. The effectiveness of games, role-playing games in the development of oral speech skills has been known for a long time. The teaching capabilities of this method are widely used in the teaching process. The development of oral communication skills and abilities is difficult to achieve without mastering this form of teaching speech activity. Play, along with work and learning, is one of the main types of human activity.

In modern higher education, which relies on the revitalization and intensification of the educational process, play activity is used in the following cases:

- as independent technologies for mastering concepts, topics and even a section of the academic subject;

- as elements of a broader technology;

- as a lesson (lesson) or part of it (introduction, explanation, consolidation, exercise, control);

- as a technology for extracurricular work.

The game form of classes is created in the classroom with the help of game techniques and situations that act as a means of stimulating, stimulating students to learning activities to develop certain speech skills. Educational games allow you to solve a whole range of problems: the application of knowledge, skills and abilities in practical activities; education of independence, will; the formation of certain approaches, positions, moral, aesthetic and ideological attitudes; fostering cooperation, sociability, sociability; development of creative abilities; adaptation to environmental conditions; communication training.

In addition to the above function, we add that games help to relieve stiffness, especially if you exclude the element of competition from them or reduce it to a minimum. A shy and weak student will feel more confident and participate in the game more actively if the goal of the game is simply to have fun and not to get grades or earn points and win. And although the element of competition often adds excitement and increases activity, it is he who creates a lot of psychological pressure on the participants, they are afraid of not coping with the task, which takes shy and 
CURRENT RESEARCH JOURNAL OF PEDAGOGICS 2(10): 17-21, October

2021 DOI: https://doi.org/10.37547/pedagogics-crjp-02-10-04

ISSN 2767-3278

(C)2021 Master Journals

\section{Crossref dol 81 Google}

Accepted 08th October, 2021 \& Published $13^{\text {th }}$ October, 2021

laggards out of the game;

- fast, spontaneous play increases attention, revives, improves perception;

- the game allows the teacher to correct students' mistakes quickly, along the way, preventing them from deeply rooted in the memory;

- games help to memorize deeply and for a long time. Students usually remember what they enjoyed doing;

- games make the learning process, sometimes difficult and tedious, fun, and this enhances the motivation for learning;

- the participants are very active during the game, because no one wants the pleasant pastime to end quickly because of him, therefore, the games make them struggle.

Games can be used at the beginning or at the end of the lesson in order to divide the lesson into two parts, relieve tension, which is decided at the discretion of the teacher. It is important that the work brings positive emotions and benefits, and, moreover, serves as an effective stimulus in a situation when the interest and motivation of students to learn Russian as a foreign language begins to wane.

But do not forget that the game is a recreation of a conventional reality, the game is subject to strict rules, has a clearly formulated didactic goal and certain rules, therefore, the introduction of game components into a traditional lesson, and even more so the complete replacement of a standard lesson with a game one, requires serious preparation from the teacher. It should also be borne in mind that the goal for the teacher and the goal that needs to be discussed with the students may differ. For example, the goal of a competitive game for students will be to complete the task correctly and first. For the teacher, the goal will be repetition, consolidation of the language material on which the game is based.

Language games contribute to the activation of students in the classroom, develop their speech initiative. The game form of work makes it possible to repeat and consolidate the learned lexical units and typical phrases, diversify the forms of the lesson and maintain the attention of students in the lesson. But play serves as a means of increasing the effectiveness of a lesson only when it is pedagogically and methodically purposeful.

Playing in foreign language lessons, students practice speech activity, which, thanks to this, is automated within certain and constantly expanding limits. However, all this is realized only with the correct selection and organization of games by the teacher. All games must be conducted in a methodically correct manner. This requires:

1. Repeat the same game several times (by substituting new lexical units).

2. Start a new game with the teacher (the role of the leader), and then transfer this role to a well-prepared student.

3. Give the game a competitive character in order to get the most out of the game.

4. Provide the players with various colorful accessories, objects, manuals.

5. Use a special dictionary that will help the teacher conduct the game in Russian as a foreign language.

6. Error correction is extremely important in educational games. It is desirable that it also be carried out in a playful form of "playing forfeits", "writing down points", etc.

Experience shows that play, albeit for a short period of time, contributes to the creation of a "language environment" in the lesson and outside it. During the game, students can psychologically rebuild and start thinking only 
CURRENT RESEARCH JOURNAL OF PEDAGOGICS 2(10): 17-21, October

2021 DOI: https://doi.org/10.37547/pedagogics-crjp-02-10-04

ISSN 2767-3278

(C)2021 Master Journals

\section{Crossref dof 81 Google}

Accepted 08th October, 2021 \& Published $13^{\text {th }}$ October, 2021

about the game, and not about the language. The game gives them the opportunity to see the practical use of knowledge, skills and abilities. The energetic pace of the game teaches them to think quickly, exercises the readiness of their language memory, and contributes to the development of the tempo of speech.

The role of play in the formation and development of these competencies can hardly be overestimated. Our research allowed us to correlate the possibilities of various types of play with one or another component of communicative competence. The nature of the game allows you to develop almost all communication skills, however, with all the obvious advantages, role-playing games are not often used in the classrooms of a non-linguistic university. This is primarily due to the fact that it is difficult for a teacher to prepare, organize and conduct a role-playing game within the few hours that are allocated for learning a foreign language.

\section{Conclusion}

The methodology of the article is based on the effective use of various modern pedagogical approaches, accompanied by game technologies in the study of Russian as a foreign language. Results: based on the synthesis and analysis of the motivational components and properties of cognitive games used in foreign language classes in non-linguistic universities, the main tasks and problems of enhancing the cognitive activity of students and improving the methods of teaching a foreign language were identified and considered. The article analyzes the structure, stages and functions of constructing role-playing training, games, considers the issues of organizing the educational process when studying the motivational potential of gaming technologies, and presents guidelines for the use of didactic games, a list of conditions for the effective implementation of gaming educational technologies in universities.

\section{ReFERENCES}

1. Mirziyev Sh.M. (2016) We will all together build a free, democratic and prosperous state of Uzbekistan. - Tashkent: Uzbekiston. - p. 39. (Мирзиеёв Ш.М. Мы все вместе построим свободное, демократическое и процветающее государство Узбекистан. Ташкент: Узбекистон,2016. - С.39.)

2. Sukhomlinsky V.A. (2019) I give my heart to the children. 1969 Publishing house Conceptual series: Education and upbringing. - p. 320. (Сухомлинский B.A. Сердце отдаю детям. 1969г Издательство Концептуальная серия: Образование и воспитание 2019, с.320)

3. Bespalko V.P. (1995) Pedagogy and progressive teaching technologies. Moscow. - p. 344. (Беспалько В.П. Педагогика и прогрессивные технологии обучения. - М., 1995, с.344)

4. Selevko G.K. (1998) Pedagogical technologies. School technology. - p. 67 (Селевко Г.К. Педагогические технологии // Школьные технологии. 1998, с.67)

5. Kavtaradze D.N. (2009) Education and play - Moscow: Education. - p. 5. (Кавтарадзе Д.Н. Обучение и игра - М.: Просвещение, 2009. - c.5.)

6. E.A. Pokrovsky. (1966) Observe and explore for yourself. - Moscow: Enlightenment. - p. 143. (Покровский Е.A. Наблюдай и исследуй сам.М.; Просвещение, 1966, 143c) 